\title{
Emergence of the Smart Society
}

\author{
Vasja Roblek* \\ Maja Meško**
}

\section{ARTICLE INFO}

Article history:

Accepted: November 152020.

Approved: December 202020.

\section{Keywords:}

Society 5.0, social changes; information society; smart citizen; smart urbanization.
A B S T R A C T

In the 1990s, humankind experienced social changes that led to the emergence of the information society. It was a new form of social existence in which the primary role is to collect, store, analyze and pass on networked information. The article focuses on the emergence of the information society and its transitions into Society 5.0. This transition came in the context of digital individualism, and its consequences are visible in the transformations in civilizing urbanization.

The article represents a theoretical retrospective based on the systematic literature review of the existing scientific and professional literature on the current human challenges in a smart environment.

(C) 2020 Published by the Institute for Development Studies, Sulkhan-Saba Orbeliani University.

\section{Introduction}

During the third industrial revolution in the 1960s, humanity underwent a social transformation that led to the emergence of the information society or Society 4.0. It was a new form of social existence in which the primary task was to collect, store, analyse, and share networked information (Webster, 2014). Technological development during the Industry 4.0 enabled the transformation from a service-oriented society to the human-centered-technology, and with loT, andbig data has come different industries and the human social environment to the process of informatization. The informatization has created the cyber-physical environment (CPE) and big data, allowing the information society to connect intangible goods as information networks (Roblek et al., 2020). After this short a brief presentation of technological evolution, Industry 4.0 brought up view concepts that are important for the development of Society 4.0 , indicating the essential characteristics of the future Society 5.0. According to the literature review on the phenomenon, the article focuses on the three characteristics of Society 5.0, namely the smart factory (or smart industrialization) (Guy, 2019; Skeggs \& Yuill, 2019), smart urbanization (Bibri, 2019; Cardullo \& Kitchin, 2019) and smart governance (Barns, 2018; Paulin, 2016; Roblek, Bach, Meško, \& Bertoncel, 2020; Webster \& Leleux, 2018). At this

\footnotetext{
* Ph.D. Student, University of Maribor, Slovenia.

** Ph.D., University of Maribor \& University of Primorska, Slovenia.
} 


\section{JOURNAL OF DEVELOPMENT TUDIES}

point, it is so worth noting some thoughts of Lefebvre (2009), such as the importance of adopting an urban social space, reducing the influence and abuse of capital. The importance of being aware of the duties and responsibilities of intelligent urban citizens are worth mentioning for an easier understanding of the globalized neoliberal and technocratic ideologies, on which the concept of the smart citizens is based in the social context of so-called smart urbanization, within which it is essential to enable the right to human resistance and prevention from technological control, or, as Zuboff (2019) said, it is a necessity to achieve consent to surveillance capitalism.

Based on social changes because of the technology development, the following research goal has been set to according to the past theoretical and practical experience about the social transformation and known theoretical background about the Society 5.0

The paper's contribution is mainly theoretical, and it has been achieved across the next sections. After introducing the theoretical framework on the information society and the digital and digital and informatisation transformations, the second section is discussed about the research method. The third section presents the theoretical questions of Society 5.0 and views on future socio-economic developments and changes in democratic processes. Finally, the paper concludes with the limitation of the study and proposals for further research.

\section{Theoretical framework about the infor- mation society and digital transformation}

1.1 Theoretical concept and historical overview of the information society

In the 1970 s, the term information society began to be used in social and political development policy. The term's growing presence was ensured by the increasing penetration of computer and communication technologies and media in the 1970s and 1980s, both in the economic environment and in education, culture, health care, and private life (Webster, 2014).

The introduction of the Internet in the early 1990s introduced information society to respond to information's proliferation and ubiquity. In the context of the 3rd industrial revolution (1960-2010), the information society established the fundamental distinction between the second and third industrial revolutions (Lyon, 2013). While the main factors of socio-economic development in the second industrial revolution were steam power and fossil fuels, they were replaced by information in the third industrial revolution. Society was thus faced with the transition from "traditional heavy industry" to a technologybased development society (Alexander, 1983; Haberl et al., 2011). Due to the ofteninaccurate understanding of a technologybased economy, the authors decided to present in Table 1 the analysis of the factors that can be used accordingly for understanding the transformation processes in the human environment.

\subsection{Impact of Industry 4.0 on the evolution of the information society}

Industry 4.0 represents a whole new way of integrating technology into society. New technologies are being researched and developed that connect the physical, digital and biological worlds. These new technologies affect all disciplines, economies, and industries (Caruso, 2018). 


\section{JOURNAL OF DEVELOPMENT TUDIES}

Table 1

Transformation processes in the human environment

\begin{tabular}{|c|c|c|}
\hline Factor & Main topics & Author \\
\hline $\begin{array}{l}\text { Profes- } \\
\text { sional }\end{array}$ & $\begin{array}{l}\text { This approach is most closely connected to Daniel Bel the } \\
\text { theory of post-industrialism. In his book The Coming of } \\
\text { Post-Industrial Society (1973), the author describes the in- } \\
\text { formation society as a society where most work is informa- } \\
\text { tive. In post-industrial economic and social systems, } \\
\text { whose most influential creators and performers are hu- } \\
\text { man beings, valid evolutionary laws apply regardless of au- } \\
\text { tomation, digitalization, and informatization. Irrespective } \\
\text { of the emerging forms of social systems, we encourage re- } \\
\text { flection on new possibilities for the social environment's } \\
\text { sustainable development. Old paradigms and patterns of } \\
\text { behavior that were effective in the former industrial sys- } \\
\text { tem are no longer appropriate. In post-industrial society is } \\
\text { going for workplaces where production, communication, } \\
\text { and analysis of information occur. The result of these pro- } \\
\text { cesses is seen in a changed state and not in the subject } \\
\text { form. Digitalization is forcing organizations in changing } \\
\text { supply chain management, procurement, and human re- } \\
\text { sources management. The consequence of Industry } 4.0 \text { is } \\
\text { a higher redundant workforce like several new work- } \\
\text { places, and this happened the first time in the history of } \\
\text { industrial revolutions }\end{array}$ & $\begin{array}{l}\text { Bel,1973; Jo- } \\
\text { seph \& Gaba, } \\
\quad 2020\end{array}$ \\
\hline Spatial & $\begin{array}{l}\text { The focus is on the networks through which the infor- } \\
\text { mation flows. Information technology in such networks } \\
\text { serves as a tool for connecting and exchanging information } \\
\text { in real-time and wherever we are networked (the impact } \\
\text { of networks on the organization of time, space, and other } \\
\text { relationships). Castells used the term "network society" } \\
\text { for such processes }\end{array}$ & Castells, 2010 \\
\hline Culture & $\begin{array}{l}\text { For the information society, television (which was initially } \\
\text { made possible by cable television), advertising, different } \\
\text { forms of lifestyle, several ethnic groups, many hybridized } \\
\text { music terms, and the World Wide Web have become es- } \\
\text { tablished. It is linked to cultural studies and an interest in } \\
\text { postmodernism }\end{array}$ & Martin, 2017 \\
\hline Theory & $\begin{array}{l}\text { The information society is dominated by theoretical infor- } \\
\text { mation/knowledge. Therefore, theoretical information } \\
\text { takes precedence over practical information and forms al- }\end{array}$ & Webster, 2014 \\
\hline
\end{tabular}




\section{JOURNAL OF DEVELOPMENT TUDIES}

\begin{tabular}{|l|l|l|}
\hline \hline & $\begin{array}{l}\text { most everything that is done. It will contrast to earlier so- } \\
\text { cieties where practical needs, knowledge and experience, } \\
\text { and habits predominate }\end{array}$ & \\
\hline
\end{tabular}

Industry 4.0 appears as a continuation of the third industrial revolution. It has enabled the digital interconnection of products, machines, tools, and more. It brings 3D and 4D printers, self-driving vehicles, $\mathrm{Al}$, and nanotechnology, but unlike the second and third industrial revolutions based on raw materials and energy, Industry $4.0 \mathrm{em}$ phasizes knowledge as an essential resource (Roblek et al., 2016).

One of the most important innovations in Industry 4.0 is robotics. Robots have been around for several decades, but the question arises as to why today's robots are different from those of the past? The difference is that robots and humans are now equal partners, meaning robots today have a higher level of artificial intelligence and can communicate with machines and humans through smart devices.

It is important to compare and list the special human abilities concerning robots' unique abilities, and it becomes clear where robots can help us and what human characteristics they can replace with their unique abilities.

With the emergence of robots in everyday human life, the question of taxing not only internet companies but also robots increase, as some scholars suggest that "whoever owns the robots rules the world" (Freeman, 2015). Holder et al. (2016) discuss the identification of the main legal and regulatory implications of robotics. According to the authors, it is time to start a dialogue in society about "how our existing legal framework may need to be adapted and changed to meet the demands of the robotics era."

In the next subsection, two of the key concepts of Industry 4.0 are presented. The development of Society 4.0 and the guarantee of a future non-mediated Society 5.0 emerge Smart factory, smart urbanization, and smart governance, which is presented in subchapter 1.3 .

\subsubsection{Smart factory}

Smart factories with fully digitized business processes that increase the overall quality of products and services. In these factories, everything needs to be connected. The focus is on the interaction between machines and semi-finished products, individual machine parts, and robots and people. For this process to succeed, the use of big data is essential. It is going for a technology that enables the collection and processing of large amounts of data in realtime (Büchi, Cugno, \& Castagnoli, 2020). As shown in Figure 1, the starting point for technological development in smart factories is the digital transformation and of computerization of all production systems. The basis for evaluation, integration, and optimal process control is data related to the processes themselves, obtained based on sensory measurements. Smart sensors with a built-in microprocessor have become a fundamental tool in measurement and enable the digitization of the acquired data. Integrated smart sensors enable the implementation of logical functions, twoway communication, and adaptation to changes in the environment, decision making, self-calibration and self-testing during commissioning. Sensors are becoming smaller and more user-friendly (Roblek, Erenda, \& Meško, 2020).

Radziwon and colleagues (2014) defined a smart factory as "a manufacturing solution that enables such flexible and 


\section{JOURNAL OF DEVELOPMENT TUDIES}

adaptive production processes that solve the problems encountered in production under dynamic and rapidly changing conditions in a world of increasing complexity." A smart factory could be associated on the one hand with automation, a combination of software, hardware, and/or mechanics that should lead to production optimization. Smart factories will play an important role in the future collaboration between different industrial and non-industrial partners, with smartness coming from creating a dynamic organization. In modular smart factories, cybernetic systems monitor physical processes, create a virtual copy of the physical world, and make decentralized decisions.

CPS communicates and collaborates with humans in real-time both within and between organizations via the loT (Munyai, Mbonyane, \& Mbohwa, 2017).

Thus, a smart factory is intrinsically "smart" enough to control and maintain its devices (Lucke, Constantinescu, \& Westkaemper, 2008). The major challenges for smart factories present standardization, security, and IT infrastructure. The actual establishment of the above elements in the broader industrial environment will take several years, which is why some prefer to use the word evolution instead of the industrial revolution (Roblek, Erenda, \& Meško, 2020).

Fig. 1. Smart factory technological development (adopted according to the Lekše, Sluga, and Rajšpelj, 2019)

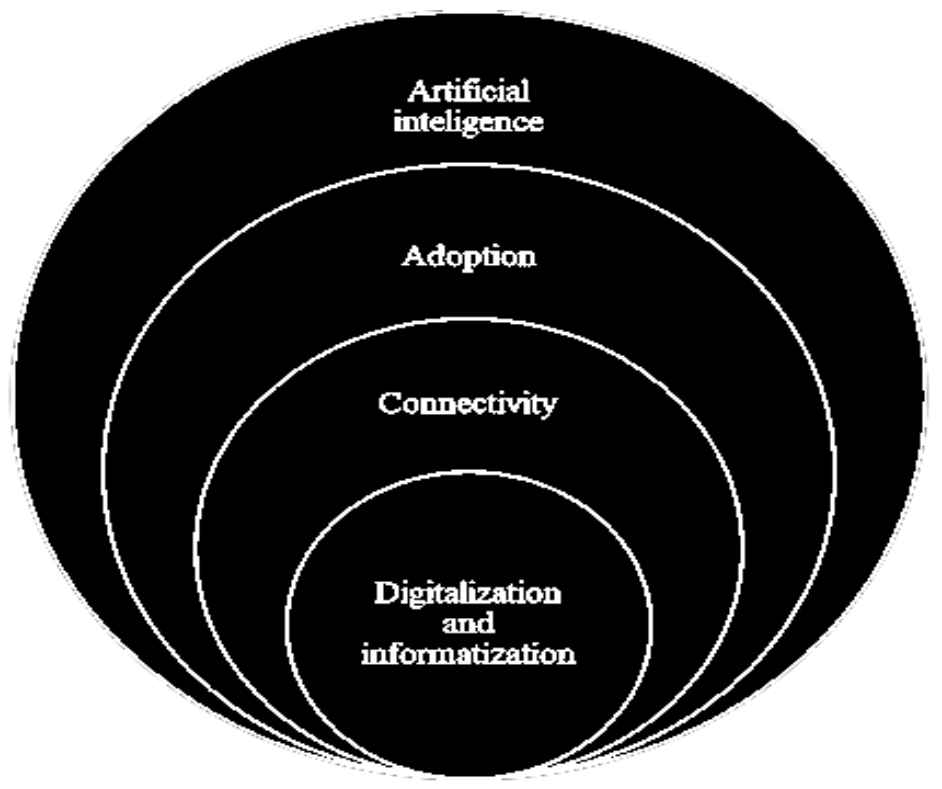




\section{JOURNAL OF DEVELOPMENT TUDIES}

\subsubsection{Smart urbanization}

Worldwide, more than $50 \%$ of the world's population already lives in urban areas, and analyses predict that this figure will rise to $70 \%$ by 2050 . For this reason, urban planning policies need to be in line with sustainable smart city (SC) development policies, as such a

change in urbanization poses a challenge to planners and developers who see rural suburbs as an opportunity and view them as indicators of sprawl. Despite some contrary views, urban systems can be more environmentally friendly than living in rural or suburban areas where people may be further away from each other, key services, and the workplace (Huo et al., 2020).

Urbanization can be seen in the high population density in a small area, which requires new forms of housing and living but also causes ecological problems and raises questions of citizen's security. , the questions of consumption and conservation of natural resources, waste management, and traffic congestions become important (Huo et al., 2020; Zoomers et al., 2017).

The issue of sustainable environmental, economic and social development of cities has thus become a very important part of the development strategies of city government, and cities are trying to integrate technological innovations into sustainability processes, which are also important for the creation of a smart community as an interactive organism in a social and technological ecosystem, for this reason, cities have started to invest in the digital transformation of the city administration 1 (Trindade et al., 2017). CPS presents the urban governance system and enables the emergence of the so-called smart community that thrives in the data economy (Kuru \& Ansell, 2020). Communities also began with the research about the modes of preparation for transforming the local community into a smart community and on the city's urbanization to make it suitable for introducing information technologies (Alawadhi et al., 2012). The Canadian Governance Center at The Ottawa University was criticized for its research approach, which they felt was too technically oriented. They suggested that research concepts should be more governance-oriented, emphasizing the importance of social relations and social capital in urban development (Albino, Berardi, \& Dangelico, 2015). The lack of generally accepted definitions that would clearly explain these terms is partly due to the different scientific fields from which they originate and partly due to changing trends. The characteristics of SC are presented in Table 2.

Table 2. Smart city characteristics (Adopted according to the Smart cities Ranking of European medium-sized cities Final report, 2007)

\begin{tabular}{|c|l|}
\hline Characteristics & Factors \\
\hline $\begin{array}{c}\text { Smart governance (citi- } \\
\text { zens participation) }\end{array}$ & $\begin{array}{l}\text { participation in decision making, political strategies, and per- } \\
\text { spectives, public and social services transparent administration }\end{array}$ \\
\hline $\begin{array}{c}\text { Smart citizens as a sub- } \\
\text { ject to Society 5.0 } \\
\text { (social and human capi- } \\
\text { tal) }\end{array}$ & $\begin{array}{l}\text { the propensity for lifelong learning, social and ethnic pluralism, } \\
\text { cosmopolitanism/openness, participation in social life, qualifi- } \\
\text { cation level, flexibility, creativity, human-centered society }\end{array}$ \\
\hline
\end{tabular}

\footnotetext{
1 The emergence of smart governance
} 


\section{JOURNAL OF DEVELOPMENT TUDIES}

\begin{tabular}{|c|l||}
\hline $\begin{array}{c}\text { Smart mobility (traffic } \\
\text { and IoT, Big Data \& arti- } \\
\text { ficial intelligence) }\end{array}$ & $\begin{array}{l}\text { availability of ICT infrastructure, sustainable, innovative, and } \\
\text { safe transport system local availability, (inter) national availa- } \\
\text { bility }\end{array}$ \\
\hline $\begin{array}{c}\text { Data-driven economy } \\
\text { (competitiveness) }\end{array}$ & $\begin{array}{l}\text { digital transformation, cyber-physical environment, human- } \\
\text { centered technologies, workforce flexibility }\end{array}$ \\
\hline $\begin{array}{c}\text { Smart environment (nat- } \\
\text { ural resources) }\end{array}$ & $\begin{array}{l}\text { the attractiveness of natural conditions, sustainable resource } \\
\text { management, environmental protection, pollution }\end{array}$ \\
\hline $\begin{array}{c}\text { Smart life (quality of } \\
\text { life) }\end{array}$ & $\begin{array}{l}\text { health conditions, a city adapted for the elderly, individual se- } \\
\text { curity, cultural institutions, quality of housing, educational in- } \\
\text { stitutions, tourist attractiveness } \\
\text { social cohesion }\end{array}$ \\
\hline
\end{tabular}

According to Gretzel et al. (2015), the adjective "smart" was added to the word city, which began a transformation based on the digitization and informatisation of city ecosystem processes. The ultimate purpose of this transformation is to ensure the optimization of both tangible and intangible resources, to optimize the operation of public services and public infrastructure, to establish effective and fair (smart) governance with enabling access to open data, and to ensure the sustainable development of the city and the wellbeing of its citizens (Pedersen, 2020). Cities need to ensure sustainable development, develop and implement data-driven solutions that enable the flow of services, operations, and functions, and design and implement strategies and policies (Angelidou et al., 2018). SCs become information hubs and knowledge repositories, where the complexity of the systems is increasing with the additional digital components that successfully use integrated computer networks and physical processes (Nitoslawski et al., 2019). The central part of the CPS presents the urban data platform, whose task is to ensure and manage the knowledge management (KM) processes. A generic KM framework for SC is defined with the ISO /

2https://www.iso.org/standard/76372.html
IEC 30145-2: 2020.2 Within the KM framework, a security system of access to and control access to SC knowledge must be provided3. The KM processes include the storage, analysis of different data collected (with sensors, cameras, users generatedcontent) for different reasons and from different sources (from different stakeholders, citizens, urban buildings, neighborhoods and streets, city administration, and businesses), their transformation into value-added information - SC knowledge (with using analytical big data systems) and their managing (Chong et al., 2018). In this way, the city government does not have to buy information from different providers but can even sell publicly insensitive information on the data market (Cassandras, 2016).

Moustaka, Maitis, Vakali, and Anthopoulos (2020) are the authors of an elaborate mechanism that allows us to recognize SC's DNA. An SC can be imagined as a molecular conglomerate in which human, environmental and socio-economic factors, often unintentionally, interact with each other to produce technological solutions. In this context, SC development strategies focus on introducing innovative technological solutions, such as the IoT, Internet of Ser-

\footnotetext{
${ }^{3}$ Interoperability of heterogeneous data and
} governance of multi-sources services) 


\section{JOURNAL OF DEVELOPMENT TUDIES}

vices (loS), artificial intelligence technologies, blockchain technologies, new sustainable materials, introducing new economic models (sharing economy, circular economy), as well as the development of smart processes that lead to the continuous development and semantic characteristics of the SC (Sepasgozar et al., 2019). The emergence of data-driven SC apps represents one of the goals of SC developers: the introduction of citizen-centric solutions of information and communication technologies, innovative products and services for the SC data-driven economy, SC development of business models, increasing the influence of citizens on political decisions and reorganization of political and public administration. In achieving this goal, they play an essential role in an innovative technological solution that influences the greater efficiency of e-services and m-services, urban infrastructure, increasing digital capabilities, and meeting stakeholders' needs (Komninos et al., 2020). Thus, SC becomes part of the discourse on sustainable urban development, in which there is a growing interest of citizens and other urban actors not only after use but also in understanding the processes of sustainable urban development in which the actors (citizens, city government, public services, etc.) are involved. It is essential to be aware that the service providers within an SC rely on data collected at different city levels and that this data is fragmented and often periodically accessed (Yigitcanlar et al., 2018). It cannot be imagining an SC without an IoT as the originator of a project on the links between smart technologies. For example, there are SC trends in using new monitoring techniques with sensors and IOT, open data, and citizens and other stakeholders' active participation, particularly through mobile devices and apps. Social networks and digital platforms have led to the development of a "community" - like a form of social interaction among online users, which is increasingly becoming an extension of the offline life of users in the socalled "online public sphere" (Komninos et al., 2019). Thus, SC can be defined as a data-driven ecosystem where stakeholders' communities can contribute and store data in different SC databases. As mobile apps represent one of the core parts, when it comes to city digitalization and transformation towards SC, they need to cover different aspects of everyday life in cities from entertainment to healthcare. Therefore, different organizations have needed to develop corresponding mobile apps to cover aspects of their interests within the targeted domain. However, the development of native mobile apps due to mobile hardware and operating systems' variability can be quite expensive and time-consuming, as it requires high programming skills and expertise. Despite the emerging popularity and adoption of cross-platform mobile application development tools and environments (such as Xamarin and Flutter), they still require a significant amount of time and involve high expertise costs (Biørn-Hansen, Grønli, \& Ghinea, 2018).

Finally, it is necessary to mention the criticisms of the Smart City concept. Krivy (2018) warns of an SC concept's incompatibility with the urban environment's unobtrusive and informal character. As such, it presents the corporatization and expansion of entrepreneurship as the goal of urbanization. It thus promotes social and urban inequalities. Another SC concept problem is that it increasingly creates a control society by using cameras and sensors for various data collections on citizens (Zuboff, 2019).

1.3. Society 5.0 as a social transformer: from technology first to human first

The aim of Society 5.0 is to further combine innovative knowledge with the use of 


\section{JOURNAL OF DEVELOPMENT TUDIES}

$\mathrm{Al}$, which is only in the concept or development phase, and to offer new human-centered technological solutions in all areas of human activity. It should be noted that Society 4.0 focuses more on technological solutions in the field of digitalization of businesses and local government processes, intending to improve the efficiency and effectiveness of the operational and financial processes of private and public organizations and public administration. On the other hand, Society 5.0 is expected to be more involved in all population groups' general social development. Thus, there would be a commercial focus on using new technologies and what is called social robotics. Thus, Al, loT, virtual reality, algorithms, CPS would lead to positive social effects that can be incorporated under this technology (Chamoso, Briones-Gonzalez, Rodriguez, \& Corchado, 2018; Song, Song, Timakum, Ryu, \& Lee, 2018):

- Home automation for independent living (home security and safety systems, motion sensors, remote monitoring, indoor air quality control, smart lighting, safe bed, smart sofa, domestic/service robots),

- health and wellbeing for functional ability (safety bracelets, activity wristbands, personal health monitor, smart medicine disappearances, exercise and memory games, smart rollator, daily medical testing) and active participation and social inclusion (entertainment and news, smart governance, online work, video chat, remote medical consultation).

As shown by the technological and social development on which Society 5.0 is built, this case is the first appearance of a "super-intelligent society" in the world (Cabinet Office, 2016). We will show what significance it will have for further social development in public administration and political administration changes.
The digitalization of public administration becomes an important theme in the 21 st century. Thus, since the mid-1990s, an e-democracy model has emerged, including e-participation, e-government, open data, and open administration. The tools of e-democracy are useful when they enable citizens to exercise real-time control over their political bodies' functioning (Pereira, Macadar, Luciano, \& Testa, 2017; Wirtz \& Birkmeyer, 2015).

In the period of digitalisation and informatisation, there is also a transfer of democratic processes into the cyberspace of technologically developed urban environments. Through the processes of digitization and informatisation of public administration, we are also experiencing the transition from e-government to "smart " governance (Bolivar \& Meijer, 2016; Lv et al., 2018).

Smart governance is a framework for democratic governance that aims to introduce a combination of digital technologies (e.g. urban data platforms as interfaces for smart governance) and innovative practices to improve the delivery of public services and the engagement of citizens, with the first phase of cooperation and the second phase of a responsible, transparent and accountable approach to decisionmaking in the development and implementation of public policies and concrete public projects (Anand \& Navio-Marco, 2018; Barns, 2018). Various authors (e.g., Chohan \& Hu, 2020; Bolivar, 2015; Castelnovo, Misuraca, \& Savoldelli, 2016) have stated that smart government, effectively used by politicians, is a management tool in public action that promotes public confidence in government institutions at all levels. Smart governments play an essential role in the initiative to develop an innovative urban environment, involving a complex dialogue between governments (supply) and citizens (demand) and other stakeholders (Pereira, 


\section{JOURNAL OF DEVELOPMENT TUDIES}

Parycek, Falco, \& Kleinhans, 2018). However, with all the technological developments affecting citizens' opportunities to participate in electoral (or decision-making) processes and in the preparation and formulation of public policy itself, it is also important to recognize that we face a crisis of credibility for democracy 21st century. In established Western democracies, there is increasing polarization (lyengar \& Westwood, 2015), leading to tribalism (Hawkins, 2019) and authoritarianism (Browning, 2018). In the era of digitization of democratic processes, we have seen the rise of tech populism (De Blasio \& Sorice, 2018; Roblek, Bach, Mesko, \& Bertoncel, 2020). The provision of so-called smart governance in the future society is understood as a set of theoretical and practical concepts that can transform society. If we want to re-
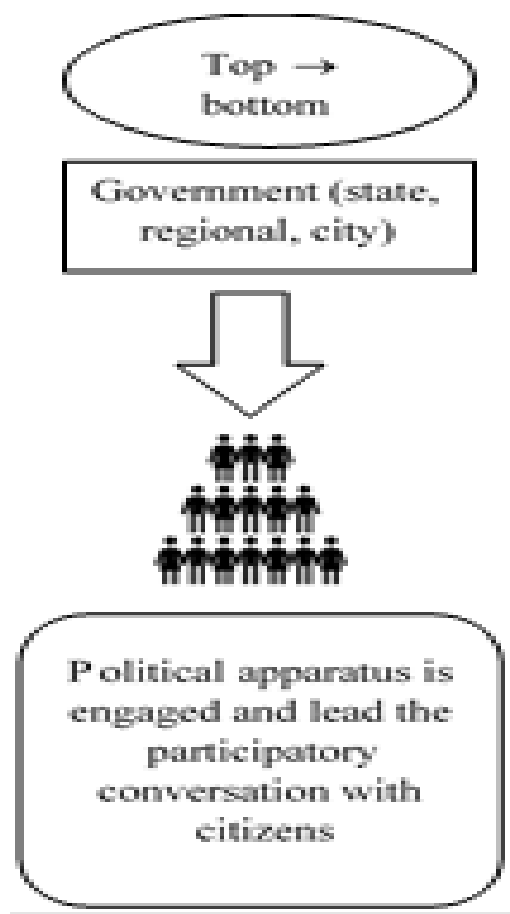

Figure 3. E-democracy approaches (adopted by Roblek, Bach, Meško, and Bertonel 2020).

Therefore, technology must give citi-
zens the right and ability to vote and enable

Therefore, technology must give citi-
zens the right and ability to vote and enable

alize this scenario, it is necessary to implement social learning policies and achieve an adequate educational structure through citizens' liberation process (Pitasi, Brasil Dib, \& Portolese, 2018) efficient and safe use of technology to support democratic processes. It must be considered that effective democracy, which includes smart governance, is no longer based on periodic elections but is increasingly becoming a form of interaction between political administration and public bureaucracy and citizens. This interaction can occur from the bottom up (from the community, city, region to the country) and vice versa from the top down (Figure 3). It depends on a social consensus on the degree of implementation of smart governance, which entails a different distribution of decision-making power in the community.

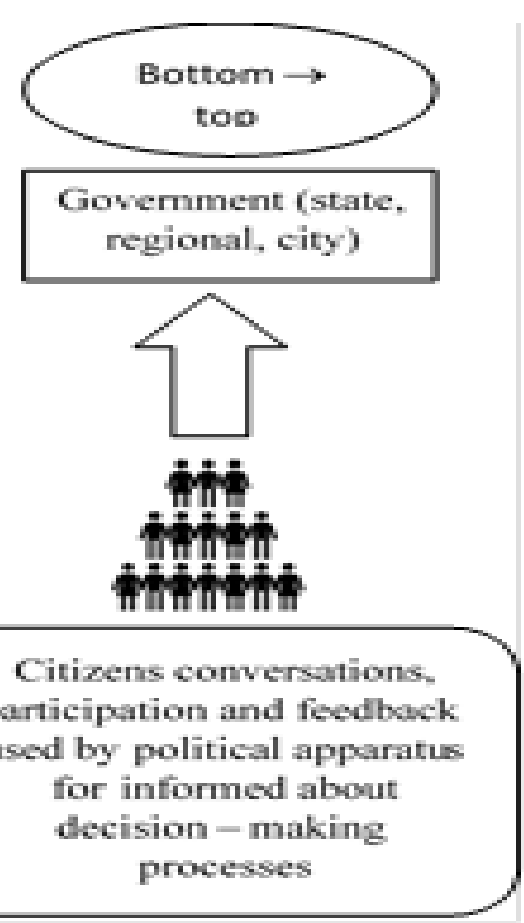

\section{Citicens comersanons.} participation and feedback. usod by political apparatus for informed about processes

Government (state, 


\section{JOURNAL OF DEVELOPMENT TUDIES}

them to vote effectively (Ford, 2002), in which they have had the opportunity to participate actively. Citizens' ability to govern depends on technologies that enable evoting (Alvarez, Levin, \& Li, 2018), online consultation/deliberation (Esau, Fleuss, \& Nienhaus, 2020), and liquid democracy (LD) (Ford, 2002; Litvinenko, 2012; Blum \& Zuber, 2016, Paulin, 2019). Technologies promise to increase the convenience and effectiveness of democratic decision-making, each of which comes with risks and significant unresolved challenges. Society 5.0 will introduce non-mediated governance, which will affect changes in the leadership paradigm. There will be a transition from a service/mediation model where officials issue documents to exercise rights to a model where rights are defined and based on requests in the information system.

The transition results will lead to the development of a network of legal systems containing a large amount of data, with detailed descriptions of the legal relationships that make up the public apparatus (Paulin, 2019, pp. 274-275).

Non-mediated governance gives citizens new mechanisms for governance. Through such mechanisms, new forms of communities can be enabled (e.g., smart city or smart village), embedded in social, political, and economic networks (Paulin, 2019). Citizens can be said to pursue their agendas and/or added value through networked governance mechanisms. This process leads to the government devolving its authority and responsibilities to various non-state actors and involves various stakeholders from the private sector, citizens, and non-governmental organizations (Hemmati, 2012).

\section{Conclusions}

The paper presents a series of activities necessary to transfer modern knowledge and new technologies, typical of the fourth industrial revolution or Industry 4.0, from research institutes and economic entities to the broader society, Society 5.0. The process can be achieved by implementing knowledge and technologies in the loT, robotics, and Big Data to transform the existing society into a fashionable smartness society (Society 5.0). In particular, the concept would better enable the adaptation of services and industrial activities to individuals' real needs, as these technologies enable advanced digital service platforms that will eventually be integrated into all areas of life.

The more intensive the transition to Society 5.0 will be, the more services and daily tasks can be provided via the cloud, e.g., on the Internet. Therefore, this data processing would send information or enable services related to applications on the telephone, the computer, and robots, among others. This will allow individuals to have more free time and the free allocation of other activities because artificial intelligence will replace manual data processing, which is typical of traditional digital algorithms. It will save much time and increase the productivity of the individual. As a result, it will positively affect increasing the value-added in the economy and enhance our people of all generations.

It is expected that with the emerging Society 5.0, developed economies will solve many social problems through innovation in technology and science. According to some estimates, the share of Japan's working population will shrink from 77 million to about 54 million people by 2050 . Economists estimate that it is precisely the demographic problem that will cause fewer and fewer young people to opt for family and children, which means that the number of older people in need of social care will increase. And not only Japanese society, which faces a similar, equally pressing de- 


\section{JOURNAL OF DEVELOPMENT TUDIES}

mographic problem, but also many European countries. The developed economies face environmental degradation problems, logistical problems (transport of people and goods within cities, between cities and rural areas, and environmental protection or reduction of greenhouse gases - climate change).

The limitations of the research are divided into content and methodological limitations. Among the content limitations, the presentation of only some aspects of Society 5.0 applies. As methodological limitations, we refer to the boundary associated with the research paradigm. This paper's limitation is that it is based on the various literature reviews and not on primary research. It is based on a topic whose development for the future capabilities of artificial intelligence depends on a parallel development of cyberspace and its importance for everyday human life. Our study should be taken as inherently biased from an analytical perspective, but at the same time, it enriches us with data that quantitative methods cannot obtain.

For future research, we suggest examining and identifying a set of good practices of Society 5.0. in Japan to assess the possibility of their implementation in other countries. We also propose future research to consider the risks that may arise in a digital society (e.g., cybersecurity, including possible cyber terrorism, relations between humans and robotics, and ethical questions related to $\mathrm{Al}$ implementation and its enabling of decision-making instead of human). Digital security is essential in Society 5.0 , as the cause of systems intrusion is mostly human error. Due to flaws in the code, it opens a computer bug that hackers can exploit for unauthorized access to systems in companies, industries, and government institutions. Data security is also crucial in smart cars, for which technology has advanced dramatically in the last few years because if hackers gain access to cars or smart traffic lights and similar technologies, they can cause chaos and accidents on the roads.

\section{References}

Alawadhi, S., Aldama-Nalda, A., Chourabi, H., Gil-Garcia, J. R., Leung, S., Mellouli, S., ... \& Walker, S. (2012). Building understanding of smart city initiatives. In Schol, J.H., Janssen, M., Wimmer, A.M., Moe, E.C., \& Skiftenes Flak, L., (Eds.), International conference on electronic government (pp. 4053). Berlin, DE: Springer.

Alexander, C. P. (1983). The new economy. Time, May, 30, 62-70.

Albino, V., Berardi, U., \& Dangelico, R. M. (2015). Smart Cities: Definitions, Dimensions, Performance, and Initiatives. Journal of Urban Technology, 22(1), 3-21. DOI: 10.1080/10630732.2014.942092

Alvarez, R. M., Levin, I., \& Li, Y. (2018). Fraud, convenience, and e-voting: how voting experience shapes opinions about voting technology. Journal of Information Technology \& Politics, 15(2), 94-105. DOI: 10.1080/19331681.2018.1460288

Anand, P. B., \& Navío-Marco, J. (2018). Governance and economics of smart cities: opportunities and challenges. Telecommunications Policy, 42(10), 795-799. DOI: 10.1016/j.telpol.2018.10.001

Angelidou, M., Psaltoglou, A., Komninos, N., Kakderi, C., Tsarchopoulos, P., \& Panori, A. (2018). Enhancing sustainable urban development through smart city applications. Journal of Science and Technology Policy Management, 9(2). DOI:

10.1108/JSTPM-05-2017-0016

Barns, S. (2018). Smart cities and urban data platforms: Designing interfaces for smart governance. City, Culture and Society, 12, 5-12. DOI: 10.1016/j.ccs.2017.09.006

Bibri, S. E. (2019). On the sustainability of smart and smarter cities in the era of big data: an interdisciplinary and transdisciplinary literature review. Journal of Big Data, 6(1), 1-64. DOI: 10.1186/s40537-019-0182-7 


\section{JOURNAL OF DEVELOPMENT TUDIES}

Biørn-Hansen, A., Grønli, T. M., \& Ghinea, G. (2018). A survey and taxonomy of core concepts and research challenges in cross-platform mobile development. ACM Computing Surveys (CSUR), 51(5), 1-34. doi:10.1145/3241739

Blum, C., \& Zuber, C. I. (2016). Liquid democracy: Potentials, problems, and perspectives. Journal of Political Philosophy, 24(2), 162-182. DOI: 10.1111/jopp.12065

Bolívar, M. P. R., \& Meijer, A. J. (2016). Smart governance: Using a literature review and empirical analysis to build a research model. Social Science Computer Review, 34(6), 673-692. DOI: $10.1177 / 0894439315611088$

Bolívar, M. P. R. (2015). Transforming city governments for successful smart cities. Cham: Springer.

Büchi, G., Cugno, M., \& Castagnoli, R. (2020). Smart factory performance and Industry 4.0. Technological Forecasting and Social Change, 150. DOI: 10.1016/j.techfore.2019.119790

Browning, C. R. (2018). The suffocation of democracy. New York Review of Books, 65(16), 14-17.

Cabinet Office (2016). 5th Science and Technology Basic Plan by the Council for Science, Technology. Retrieved from http://www8.cao.go.jp/cstp/english/basic/5thbasicplan.pdf.

Cardullo, P., \& Kitchin, R. (2019). Smart urbanism and smart citizenship: The neoliberal logic of 'citizen-focused'smart cities in Europe. Environment and Planning C: Politics and Space, 37(5), 813-830. DOI:

$10.1177 / 0263774 \times 18806508$

Caruso, L. (2018). Digital innovation and the fourth industrial revolution: epochal social changes?. Ai \& Society, 33(3), 379-392. DOI: 10.1007/s00146-017-0736-1

Cassandras, C. G. (2016). Smart cities as cyberphysical social systems. Engineering, 2(2), 156-158. DOI: 10.1016/J.ENG.2016.02.012

Castelnovo, W., Misuraca, G., \& Savoldelli, A. (2016). Smart cities governance: The need for a holistic approach to assessing urban participatory policymaking. Social Science Computer Review, 34(6), 724-739. DOI: $10.1177 / 0894439315611103$
Castells, M. (2010). Globalisation, networking, urbanisation: Reflections on the spatial dynamics of the information age. Urban Studies, 47(13), 2737-2745. DOI: 10.1177/0042098010377365

Chamoso, P., Pérez-Ramos, H., \& García-García, Á. (2014). ALTAIR: Supervised Methodology to Obtain Retinal Vessels Caliber. ADCAIJ: Advances in Distributed Computing and Artificial Intelligence Journal. Salamanca, 3(4). DOI: 10.14201/ADCAIJ2014345060

Chohan, S. R., \& Hu, G. (2020). Success factors influencing citizens' adoption of IoT service orchestration for public value creation in smart government. IEEE Access, 8. doi: 10.1109/ACCESS.2020.3036054

Chong, M., Habib, A., Evangelopoulos, N., \& Park, H. W. (2018). Dynamic capabilities of a smart city: An innovative approach to discovering urban problems and solutions. Government Information Quarterly, 35(4), 682-692. doi:10.1016/j.giq.2018.07.005

Davis, N. (2016). What is the fourth industrial revolution? Retrieved from https://www.weforum.org/agenda/2016/01/what-is-thefourth-industrial-revolution/

De Blasio, E., \& Sorice, M. (2018). Populism between direct democracy and the technological myth. Palgrave Communications, 4(1), 15. DOI: 10.1057/s41599-018-0067-y

Ensmenger, N. (2012). The digital construction of technology: Rethinking the history of computers in society. Technology and Culture, 53(4), 753-776.

Esau, K., Fleuß, D., \& Nienhaus, S. M. (2020). Different Arenas, Different Deliberative Quality? Using a Systemic Framework to Evaluate Online Deliberation on Immigration Policy in Germany. Policy \& Internet. In press. DOI: $10.1002 /$ poi3.232

Farrell, D. (2003). The real new economy. Harvard Business Review, 81(10), 104-12.

Freeman, R.B. (2015). Who owns the robots rules the world. IZA World of Labor, Vol. 5. Retrieved from https://wol.iza.org/uploads/articles/5/pdfs/who-owns-the-robotsrules-the-world.pdf 


\section{JOURNAL OF DEVELOPMENT TUDIES}

Ford, B. A. (2002). Delegative democracy. Retrieved from https://infoscience.epfl.ch/record/265695

Gretzel, U., Werthner, H., Koo, C., \& Lamsfus, C. (2015). Conceptual foundations for understanding smart tourism ecosystems. Computers in Human Behavior, 50, 558-563.

Guy, J. S. (2019). Digital technology, digital culture and the metric/nonmetric distinction. Technological Forecasting and Social Change, 145, 55-61. DOI: 10.1016/j.techfore.2019.05.005

Haberl, H., Fischer-Kowalski, M., Krausmann, F., Martinez-Alier, J., \& Winiwarter, V. (2011). A socio-metabolic transition towards sustainability? Challenges for another great transformation. Sustainable Development, 19(1), DOI: 1-14. 10.1002/sd.410

Hawkins, K. A. (2019). The ideational approach. In de la Torre, C. (Ed.), Routledge handbook of global populism (pp, 57-72). Abingdon, OX: Routledge.

Holder, C., Khurana, V., Harrison, F., \& Jacobs, L. (2016). Robotics and law: Key legal and regulatory implications of the robotics age (Part I of II). Computer Law \& Security Review, 32(3), 383-402. DOI: 10.1016/j.clsr.2016.03.001

Horowitz, M. C. (2019). When speed kills: Lethal autonomous weapon systems, deterrence and stability. Journal of Strategic Studies, 42(6), 764-788. DOI: 10.1080/01402390.2019.1621174

Hughes, C., \& Southern, A. (2019). The world of work and the crisis of capitalism: Marx and the Fourth Industrial Revolution. Journal of Classical Sociology, 19(1), 59-71. DOI: $10.1177 / 1468795 \times 18810577$

Huo, T., Li, X., Cai, W., Zuo, J., Jia, F., \& Wei, H. (2020). Exploring the impact of urbanisation on urban building carbon emissions in China: Evidence from a provincial panel data model. Sustainable Cities and Society, 56, 102068. DOI: 10.1016/j.scs.2020.102068

lyengar, S., \& Westwood, S. J. (2015). Fear and loathing across party lines: New evidence on group polarisation. American Journal of Political Science, 59(3), 690-707. DOI: 10.1111/ajps.12152
Jorgenson, D. W. (2001). Information technology and the US economy. American Economic Review, 91(1), 1-32. DOI: 10.1257/aer.91.1.1

Joseph, J., \& Gaba, V. (2020). Organizational structure, information processing, and decision-making: a retrospective and road map for research. Academy of Management Annals, 14(1), 267-302. DOI: 10.5465/annals.2017.0103

Komninos, N., Kakderi, C., Panori, A., \& Tsarchopoulos, P. (2019). Smart city planning from an evolutionary perspective. Journal of Urban Technology, 26(2), 3-20. DOI: 10.1080/10630732.2018.1485368

Komninos, N., Kakderi, C., Collado, A., Papadaki, I., \& Panori, A. (2020). Digital Transformation of City Ecosystems: Platforms Shaping Engagement and Externalities across Vertical Markets. Journal of Urban Technology, In Press. DOI: 10.1080/10630732.2020.1805712

Krivý, M. (2018). Towards a critique of cybernetic urbanism: The smart city and the society of control. Planning Theory, 17(1), 8-30. DOI: $10.1177 / 1473095216645631$

Kuru, K., \& Ansell, D. (2020). TCitySmartF: A comprehensive systematic framework for transforming cities into smart cities. IEEE Access, 8, 18615-18644. DOI: 10.1109/ACCESS.2020.2967777

Lefebvre, H. (2009). State, space, world: Selected essays. Minneapolis, MN: University of Minnesota Press.

Litvinenko, A. (2012). Social media and perspectives of liquid democracy on the example of political communication of Pirate Party in Germany. In Gasco, M. (Ed) The Proceedings of the 12th European Conference on e-Government in Barcelona (pp. 403-408), Barcelona 14-15 June 2012. Barcelona: Institute of Public governance and management ESADE Barcelona.

Lucke, D., Constantinescu, C., \& Westkämper, E. (2008). Smart factory-a step towards the next generation of manufacturing. London, UK: Springer.

Lv, Z., Li, X., Wang, W., Zhang, B., Hu, J., \& Feng, S. (2018). Government affairs service platform for smart city. Future Generation 


\section{JOURNAL OF DEVELOPMENT TUDIES}

Computer Systems, 81, 443-451. DOI:

10.1016/j.future.2017.08.047

Lyon, D. (2013). The information society: Issues and illusions. Oxford, UK: Polity Press.

Martin, W. J. (2017). The global information society. Thousand Oaks, FL: Taylor \& Francis.

Moustaka, V., Maitis, A., Vakali, A., \& Anthopoulos, L. G. (2020). CityDNA Dynamics: A Model for Smart City Maturity and Performance Benchmarking. In Seook-Jin, E. \& Johor, L. (Eds.), Companion Proceedings of the Web Conference 2020 (pp. 829-833). New York, NY: The Association for Computing Machinery.

Munyai, T. T., Mbonyane B. L., \& Mbohwa, C. (2017). Productivity improvement in manufacturing SMEs: Application of work-study. Boca Raton, FL: Taylor \& Francis Productivity Press.

May, C. (2002). The information society: A sceptical view. Cambridge, UK: Polity.

Nitoslawski, S. A., Galle, N. J., Van Den Bosch, C. K., \& Steenberg, J. W. (2019). Smarter ecosystems for smarter cities? A review of trends, technologies, and turning points for smart urban forestry. Sustainable Cities and Society, 51, 101770. DOI: 10.1016/j.scs.2019.101770

Paulin, A. (2016). Information smart cities governance? Let us first understand the atoms!. Journal of the Knowledge Economy, 7(2), 329-343. DOI: 10.1007/s13132-0160368-6.pdf

Pedersen, K. (2020). What can open innovation be used for, and how does it create value?. Government Information Quarterly, 37(2), 101459. DOI: 10.1016/j.giq.2020.101459

Pereira, G. V., Parycek, P., Falco, E., \& Kleinhans, R. (2018). Smart governance in the context of smart cities: A literature review. Information Polity, 23(2), 143-162. DOI: 10.3233/IP-170067

Pitasi, A., Brasil Dib, N., \& Portolese, G. (2018). Legislative innovation. Towards a global law. Making process: the case of global citizenship policy modelling. International Review of Sociology, 28(3), 392-402. DOI: 10.1080/03906701.2018.1529102

Radziwon, A., Bilberg, A. Bogers, M., \& Madsen,. E. S. (2014). The smart factory: explor- ing adaptive and flexible manufacturing solutions. Procedia Engineering 69, 11841190. DOI: 10.1016/j.proeng.2014.03.108

Roblek, V., Bach, M. P., Meško, M., \& Bertoncel, T. (2020). Best practices of the social innovations in the framework of the e-government evolution. Anfiteatro Economic, 22(53), 275-302. DOI: 10.24818/EA/2019/53/275

Roblek, V., Erenda, I., \& Mesko, M. (2020). Fundamental changes in the organisational processes. In Machado, C. \& Davim, J. P. (Eds.), Industry 4.0: Challenges, Trends, and Solutions in Management and Engineering (pp. 161-190). Boca Raton, FL: CRC Press/Taylor \& Francis Group.

Russell, S., Dewey, D., \& Tegmark, M. (2015). Research priorities for robust and beneficial artificial intelligence. Ai Magazine, 36(4), 105-114. DOI: 10.1609/aimag.v36i4.2577

Sepasgozar, S. M., Hawken, S., Sargolzaei, S., \& Foroozanfa, M. (2019). Implementing citizen-centric technology in developing smart cities: A model for predicting the acceptance of urban technologies. Technological Forecasting and Social Change, 142, 105-116. DOI: 10.1016/j.techfore.2018.09.012

Skeggs, B., \& Yuill, S. (2019). Subjects of value and digital personas: reshaping the bourgeois subject, unhinging property from personhood. Subjectivity, 12(1), 82-99. DOI: 10.1057/s41286-018-00063-4

Skobelev, P. O., \& Borovik, S. Y. (2017). On the way from Industry 4.0 to Industry 5.0: From digital manufacturing to digital society. Industry 4.0, 2(6), 307-311.

Song, I. Y., Song, M., Timakum, T., Ryu, S. R., \& Lee, H. (2018). The landscape of smart ageing: Topics, applications, and agenda. Data \& Knowledge Engineering, 115, 68-79. DOI: 10.1016/j.datak.2018.02.003

Trindade, E. P., Hinnig, M. P. F., Moreira da Costa, E., Marques, J. S., Bastos, R. C., \& Yigitcanlar, T. (2017). Sustainable development of smart cities: A systematic review of the literature. Journal of Open Innovation: Technology, Market, and Complexity, 3(3), 11. DOI: $10.1186 / \mathrm{s} 40$ 


\section{JOURNAL OF DEVELOPMENT TUDIES}

Webster, C. W. R., \& Leleux, C. (2018). Smart governance: Opportunities for technologically-mediated citizen co-production. Information Polity, 23(1), 95-110. DOI: 10.3233/IP-170065

Webster, F. (2014). Theories of the information society. London, UK: Routledge.

Wirtz, B. W., \& Birkmeyer, S. (2015). Open government: Origin, development, and conceptual perspectives. International Journal of Public Administration, 38(5), 381-396. DOI: 10.1080/01900692.2014.942735

Yigitcanlar, T., Kamruzzaman, M., Buys, L., loppolo, G., Sabatini-Marques, J., da Costa, E. M., \& Yun, J. J. (2018). Understanding 'smart cities': Intertwining development drivers with desired outcomes in a multidimensional framework. Cities, 81, 145-160. DOI: 10.1016/j.cities.2018.04.003

Yoo, J. (2017). Embracing the machines: rationalist war and new weapons technologies. California Law Review, 105, 443. DOI: 10.15779/Z38D50FXOX

Zoomers, A., Van Noorloos, F., Otsuki, K., Steel, G., \& Van Westen, G. (2017). The rush for land in an urbanising world: From land grabbing toward developing safe, resilient, and sustainable cities and land-

scapes. World Development, 92, 242-252. DOI: 10.1016/j.worlddev.2016.11.016

Zuboff, S., 2019. The age of surveillance capitalism: The fight for a human future at the new frontier of power. London, UK: Profile Books Ltd. 